\title{
Issues of Online Training Development in Higher Education System in the Context of Economy Digitalization
}

\author{
Baryshnikov S.V.* \\ Voronezh State University of Engineering Technologies \\ Voronezh, Russia \\ E-mail: bsv.kfv@yandex.ru \\ Nekrasova T.A. \\ Voronezh State Technical University \\ Voronezh, Russia \\ E-mail: nekrasova-tatiana@list.ru
}

\author{
Koval L.V. \\ Voronezh State Technical University \\ Voronezh, Russia \\ E-mail:kov_lv@mail.ru \\ Purgaeva I.A. \\ Voronezh State Technical University \\ Voronezh, Russia \\ E-mail: tolsira@yandex.ru
}

\author{
Frolova V.P. \\ Voronezh State University of Engineering Technologies \\ Voronezh, Russia \\ e-mail: verairafrolova@mail.ru
}

\begin{abstract}
Digital economy growth stimulates the development of such innovative direction in higher education as online training. Online education provides students with access to the resources of the leading higher educational institutions of the country and helps them to individualize their study. At the same time, the introduction of online courses into the educational process of higher schools faces a number of problems that are both objective and subjective in nature. This paper deals with the subjective problems of online education development in the higher education system in the context of economy digitalization. In particular, the authors considered the issues related to the student attitude to online courses, as well as to learning motivation and self-regulation. The latter plays more significant role for online learning models than for a traditional one. The study is based on empirical material collected in two Voronezh Universities by means of psychodiagnostic and sociological methods. The analysis showed that students do not have a strong desire to take online courses. The ineffective functioning of online courses is also caused by the lack of necessary motivation to study of the majority of the students. The main motive for learning of a large part of students is getting a diploma, rather than acquiring knowledge or mastering a profession. At the same time, the general level of student self-regulation is such that if they are motivated, they are able to complete online courses training successfully. The article emphasizes the fact that now, students are not psychologically ready for online education, and the active introduction of online courses into the higher education system may have mixed effects.
\end{abstract}

Keywords - online training, online courses, higher education, learning motivation, general level of self-regulation.

\section{INTRODUCTION}

Nowadays digital technology is quickly spread into various spheres of public life: economy $[1,2]$, health care, education system etc.

Online training becomes widespread as innovative way of learning. It is an important trend of education digitalization around the world.

Online training introduction into the country educational system is actively supported by the state within the framework of national projects. One of these projects is the national project «Education» for the period of 2019-2024. According to the Passport of the National Project «Education», it is planned to develop an integration platform for continuous education (professional training and additional learning) by December 31, 2020 [3].

Thanks to the academic digital platform, students will have an opportunity to:

- use educational resources, not only of their University, but also of other leading higher educational institutions in their learning process;

- arrange an individual educational trajectory;

- get additional professional education.

At the same time, the transition to online education creates the number of difficulties that can lead to the training quality decrease, to a low academic performance, and mass dropout of students. 
Western universities have already faced objective and subjective problems related to online training in the higher education system. This fact is demonstrated by the researches of such foreign authors, as Han H., Johnson S.D. [4], Fryer L.K., Bovee H.N., 2016 [5], Cho M. H., Tobías S., 2016 [6], Kmser-Ross M.J., Waters R.D. [7], Xíhs W., Xing W., Chen X., Stein J., 2016 [8]

Some papers deal with the subjective factors that should be taken into account when introducing online courses into the education system in general, and into the higher education system, in particular. Some kind of subjective factors that seriously affect the results of online training include peculiarities of internal motivation for learning and selfregulation ability.

The role of motivation and self-regulation in the transition to online training is of great importance due to the decrease of a lecturer controlling function and the increase of the independent work percentage.

Therefore, before introducing online courses into higher education process (this process is activated after the development of integration platform for continuous education), it should be determined such subjective factors as student attitude to online courses and psychological readiness to take them.

This paper is devoted to the study of these online training aspects.

The purpose of the research is to identify the subjective problems of the online training development in the higher education system in the context of economy digitalization.

Research problems include:

- the determination of student attitude to different models of online courses;

- the assessment of student psychological readiness to take online courses.

\section{RESEARCH METHODS}

The methodological basis of this research is the works of Russian scientists who consider the problems of distance and e-learning. Conducting the study, we also used general scientific methods such as analysis, synthesis, and others.

The identification of subjective problems of the online training development in the higher education system in the context of economy digitalization is based on empirical and theoretical research methods.

The empirical material was collected by means of sociological and psychodiagnostic research methods.

The attitude of students to traditional education and online training was determined by the questionnaire method.

In January-February 2020, it was interviewed 150 students of the first and the second courses from Voronezh State University of Engineering Technologies (VSUET) and Voronezh State Technical University (VSTU).
To study the psychological readiness of students to take online courses, it was used such a psychodiagnostic method, as the questionnaire method.

The identification of student motivation was carried out using the method «Motivation of training in higher school», proposed by T.I. Ilyina [16].

The method is aimed at the determination of key learning motives. It contains three scales («acquiring knowledge »; «mastering a profession»; «getting a diploma»). It allows the researchers to determine the proportion of the students who are motivated for getting education, and the proportion of students who are focused on formal learning just for getting a diploma.

The assessment of students' ability to self-regulate their learning activities was conducted by using the method «Selfregulation Behavior Style - SSB-98», developed under the guidance of V.I. Morosanova [17]. Based on the study of the scale indicators "General level of self-regulation», it can be concluded that students are able to carry out independent work when learning.

System analysis method was used to interpret the results obtained.

\section{RESULTS}

Online training is a new direction in the education system. This is a variety of e-learning and distance learning, «a way to organize the process of independent study of training materials using educational environment based on Internet technologies and training by means of the Internet and multimedia» [15].

A special case of online training is online courses that are «logically and structurally completed training unit, methodically provided with a unique set of systematized electronic training and control tools» [11].

Online course history began with Mass Open Online Courses (MOOC). On the base of the digital platforms MOOC, anyone can take a particular course and pass an exam online.

In Russia, the national platforms MOOC have been functioning since September 1, 2015. MOOC are also available at the leading universities of the country, such as Moscow State University named after M.V. Lomonosov, Higher School of Economics, Moscow Institute of Physics and Technology, etc.

Currently, there are some opportunities for the wide use of online courses in the higher education system. Being actively supported by the state, it is conducted work aimed at the development of the integration platform for continuous education (professional training and additional education) for University students. This work will have completed by the end of 2020.

Today, according to Karasik A.A., the Director of the Institute of Open Education Technologies of the Ural Federal University named after the first President of Russia B. N. Yeltsin, it can be distinguished three operating models of online courses in the system of higher education [18] 
- mixed learning (online course is combined with traditional training);

- online course, accompanied by the lecturer from the University where students study;

- independent study at the online course on the base of the tutor support from another University where the course was developed.

Training quality of the students when taking online courses will be largely determined by their attitude to the courses, their high motivation for learning and their self-regulation ability.
During the survey, the researchers revealed the attitude of students of technical faculties of VSUET and VSTU to the traditional model and models of online learning (mixed learning model, model «online course, accompanied by the lecturer», model «online course on the base of the tutor support»).

Figure 1 shows the results of the sociological survey on students' preferences when choosing a learning model to study humanitarian and socio-economic disciplines.

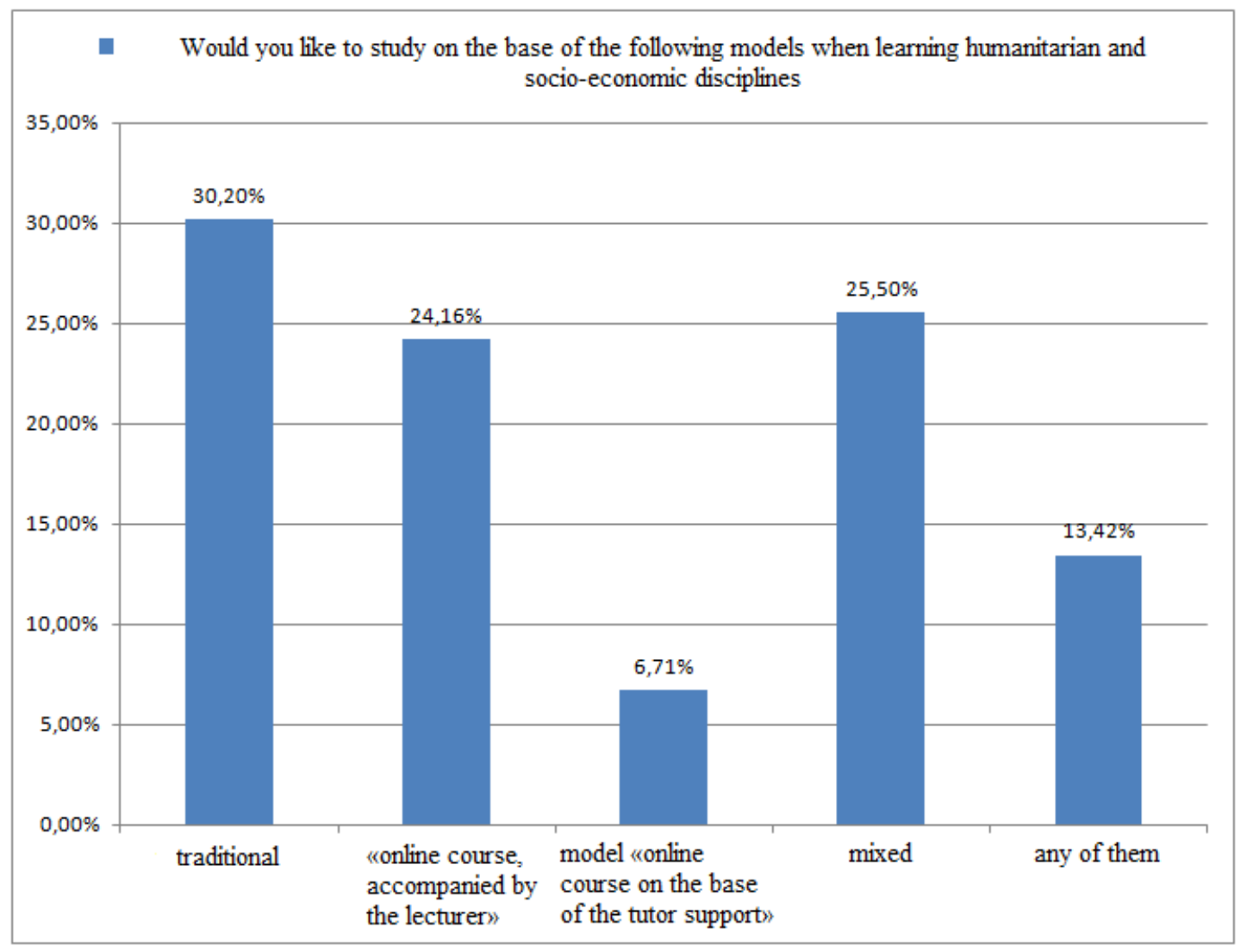

Fig. 1. Students' preferences when choosing a learning model to study humanitarian and socio-economic disciplines

The data presented in figure 1 , demonstrates that only $30.1 \%$ of students of technical directions prefer the traditional model of education with classroom lectures and practical classes in humanitarian and socio-economic disciplines.

Almost the same number of students chose online education, $24.1 \%$ of them preferred model of the "sonline course accompanied by a lecturer» and $6.71 \%$ expressed a preference for the model of «online course on the base of the tutor support».

About a quarter of students $(25.5 \%)$ agreed to compromise. $13.42 \%$ of the students did not care about the model (traditional or innovative) of their studying humanitarian and socio-economic disciplines.
Figure 2 shows the survey data on students' preferences when choosing a learning model for natural and mathematical disciplines.

According to the conducted survey, it can be seen that the majority of the students chose the traditional model when studying natural and mathematical disciplines (figure 2). Only $14.77 \%$ of them would like to take «online courses accompanied by a lecturer», while $4.03 \%$ would like to have a model «online course on the base of the tutor support».

The attitude of the students to different learning models of disciplines of professional block can be judged by the information graphically shown in figure 3 . 


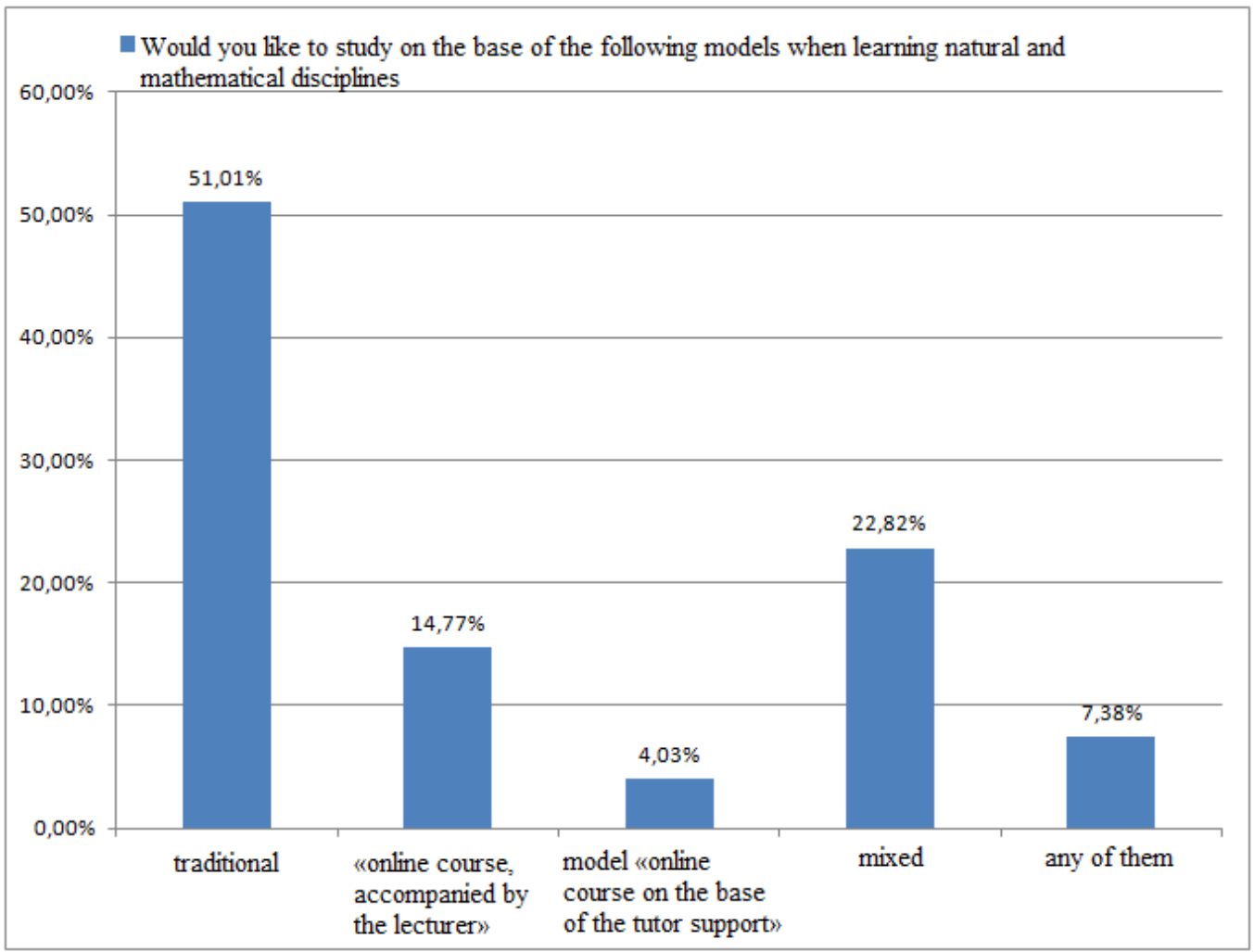

Fig. 2. Students' preferences when choosing a learning model to study natural and mathematical disciplines

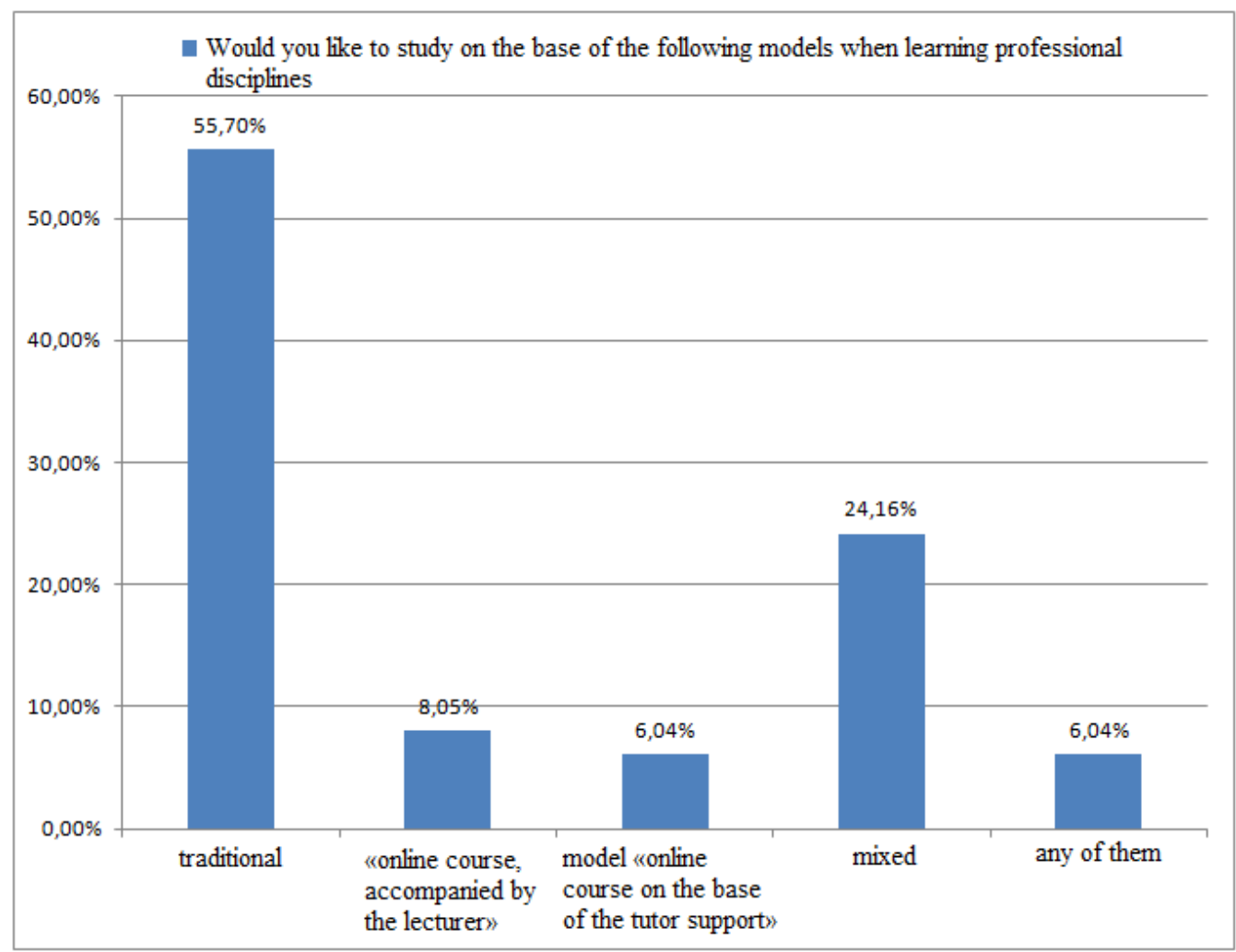

Fig. 3. Students' preferences when choosing a learning model to study professional disciplines 
According to the empirical data (figure 3), students of technical fields would like to keep the traditional model of training when studying professional disciplines. This model was chosen by $55.7 \%$ of respondents.

Only $8.05 \%$ of students would like to take the «online course accompanied by a lecturer» and $6.71 \%$ of respondents want to study at the "online course on the base of the tutor support».

Almost a quarter of the students positively assesses training based on the mixed model and $6.04 \%$ don't care about the model they are offered.

Thus, now, more than $50 \%$ of the future engineers from two Voronezh Universities would like to study natural, mathematical and professional disciplines in a traditional way. Considerably smaller proportion of students would like to take online courses to study disciplines mentioned above without any types of classroom teaching. As for learning humanitarian disciplines, the picture is different. Only one-third of the students want to study in the classrooms. Other students, except those who are undecided $(13.42 \%)$, are in favor of one of the three online learning models.

During the introduction of online courses into the higher education system, it is important to take into account not only the students attitude to them, but also their psychological readiness for online learning. In particular, students should be motivated to get a good education with a diploma, but not just to get a diploma, poorly supported by knowledge, skills and abilities.

Students differentiation according to the key motives of learning («acquiring knowledge», «mastering a profession», «getting a diploma») was carried out using the method developed by T.I. Ilyina. The results are presented in figure 4 .

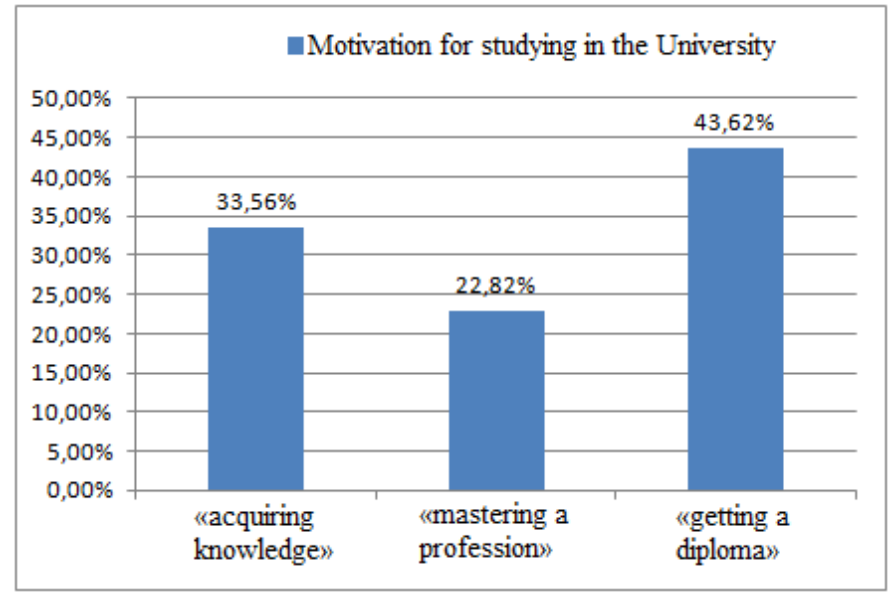

Fig. 4. Differentiations of students according to the key motive of learning

The proportion of students motivated to «get a diploma», as shown in figure 4 , is $43.62 \%$. It exceeds the proportion of students with predominant motives for «acquiring knowledge» $(33.56 \%)$ and «mastering a profession» $(22.82 \%)$.

It should be noted that the change of the traditional model by online training model will lead to the education quality decrease of students with a predominant motivation for «mastering a profession».

Students will not develop properly general cultural and professional competences in such situation. Their «desire to get a diploma by the formal learning, their attempts to find any easy ways of passing exams and tests» [16] when taking online courses will not be limited by the lecturer control. These students will have more opportunities to achieve their goals and get a diploma without learning in a proper way.

Thus, according to such criteria as motivation for learning activity, a significant part of students is not ready to take online training.

One of the indicators of student psychological readiness for online courses is the self-regulation level in the whole, and in relation to learning activities, in particular. The general level of students' behavior self-regulation was determined by using the methodology developed under the guidance of V.I. Morosanova. The results of the survey are presented in the histogram in figure 5 .

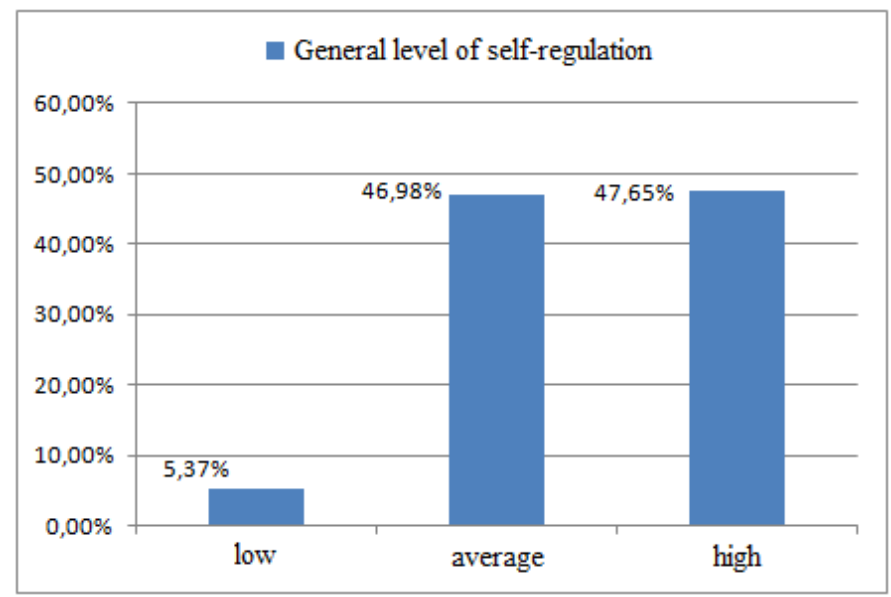

Fig. 5. Differentiation of students by the general level of self-regulation

As it can be seen from the histogram in figure 5, the students mostly have a high and average level of general selfregulation (47.65 and $46.98 \%$, respectively). Students with an average and high level of self-regulation are able to move independently to their goals, because «the higher the conscious regulation general level, the easier it is for a person to master new types of activity, to feel more confident in unfamiliar situations, and the more stable their success in the normal types of activity» [17]. Accordingly, it can be assumed that students with an average and high general level of selfregulation, being motivated for acquiring knowledge and mastering a profession, will be able to get education via online courses successfully.

\section{DISCUSSIONS}

The introduction of online courses into the higher school system faces a number of problems that are both objective and subjective in nature. 
The subjective factors that create difficulties for the effective functioning of the online courses in the University system include such ones as the attitude of the students to the online courses and their psychological readiness for online learning.

The study showed that students do not have a strong desire to take online courses. The majority of the students support the traditional learning model when studying natural, mathematical and professional disciplines. Only a small part of students tends to study humanitarian, social and economic disciplines via online courses.

Students are ready to take online courses related to the general level of activity self-regulation development. The average and high level of students self-regulation, allows supposing that they will be able to study independently on regular basis. At the same time, independence and activity in learning are possible if students are motivated for «acquiring knowledge» and «mastering a profession». However, these motives are not the leading ones for the majority of the students. The most common motivation for learning is the motive of «getting a diploma». When switching to online training for students aimed at getting good education with a diploma, the quality of their knowledge will decrease because of the lack of internal motivation for learning and lecturer stimulation of their educational activities.

\section{CONCLUSION}

The development of such innovative approach in the higher education system as online training is a complex and ambiguous process. Possible difficulties that higher education will have to face after the introduction of online courses into practice include problems related to the student motivation and self-regulation. A number of researchers assume this fact [13, 15, 19, 20]. Empirical material of the research conducted supports their assumptions.

The results presented in the paper suggest that it is impossible to accept the position of the rector of the National Research University «Higher school of Economics» Ya.I. Kuzminov, who said: «the Ministry of Education and Science and Federal Education and Science Supervision Service should be stricter to make Universities include the online courses, which are read by leading scientists, in educational programs and it is better than let students take the course taught by the local Assistant Professor» [21].

We should not agree with such recommendation. Obligatory introduction of online courses will lead to the decrease of the student educational quality and a large dropout rate of the first and the second courses students who are psychologically not ready for online training. This fact has been proved by the Western experience. As early as in 2013, foreign publications noted that, according to Stanford University, the dropout rate from some large-scale online courses was up to $90 \%$ [22]. If traditional education is replaced by online courses everywhere, it can destroy the higher education system.

\section{References}

[1] N.A. Serebryakova, I.V. Avdeev, "The content of structural transformations of the regional economy, adequate to the requirements of digitalization", Proc. of the Voronezh State Univer. of Engineer. Technol., vol. 80, no. 4, pp. 408-412, 2018. Retrieved from: https://doi.org/10.20914/2310-1202-2018-4-408-412

[2] Y.V. Narolina, T.V. Sabetova, N.V. Shabutskaya, N.V. Gryshchenko «The influence of innovative development on economic security of the region». Proceedings of the Voronezh State University of Engineering Technologies. vol. 81, no. 1, pp. 457-463, 2019. Retrieved from: https://doi.org/10.20914/2310-1202-2019-1-457-463

[3] Passport of the National Project «Education» (approved by the Presidium of the President's Council of the Russian Federation for strategic development and national projects, Protocol of 24.12.2018, no. 16). Consultant Plus. Retrieved from: http://www.consultant.ru/ document/cons_doc_LAW_319308/f1ee4532412ce736d7fe9c30a420d9 bb7959cc48/

[4] H. Han, S.D. Johnson, "Relationship between Students'Emotional Intelligence, Social Bond, and Interactions in Online Learning”, Ed. Technol. \& Society, vol. 15, iss. 1, pp. 78-89, 2012.

[5] L.K. Fryer, H.N. Bovee, "Supporting students' motivation for elearning: Teachers matter on and offline", The Internet and Higher Ed., vol. 30, no. 7, pp. 21-29, 2016.

[6] M-H. Cho, S. Tobias, "Should Instructors Require Discussion in Online Courses? Effects of Online Discussion on Community of Inquiry, Learner Time, Satisfaction, and Achievement", The int. rev. of res. in open and distributed learn., vol. 17, iss. 2, pp. 123-140, 2016.

[7] M.J. Kruger-Ross, R.D. Waters, «"Predicting online learning success: Applying the situational theory of publics to the virtual classroom", Comput. \& Ed., vol. 61, no. 2, pp. 176-184, 2013.

[8] W. Xing, X. Chen, J. Stein, "Marcinkowski,Michael Temporal predication of dropouts in MOOCs: Reaching the low hanging fruit through stacking generalization", Comput. in Human Behavior, vol. 5 , no. 5, pp. 119-129, 2016.

[9] N.V. Barinova, 'Problems of distance and e-education development in Russia', IT portal, vol. 2, no. 14, 2017. Retrieved from: http://itportal.ru/science/tech/problemy-razvitiya-distantsionnogo-/

[10] A.D. Voloshinova, "Social media in the pedagogical process: foreign researchers experience in the context of the Russian higher school problems", Azimuth of sci. res.: pedag. and psychol., vol. 6, no. 3(20), pp. 55-58, 2017.

[11] N.V. Grechushkina, "Online course: definition and classification", Higher ed. in Russ., vol. 27, no. 6, pp. 125-134, 2018.

[12] A.N. Golubeva, «Mass open online courses: concept, classification and experience of application in the system of higher education», Questions of pedagogy. 2017, no. 7, pp. 25-29.

[13] N. L. Romanova, "Online courses as an innovative form of distance learning", Pedag. of higher ed., vol. 2, no. 12, pp. 5-8, 2018.

[14] Zh.V. Smirnova, Zh.V. Chaikina, "Distance education as a learning management process", Internet J. Mir nauki, vol. 5, no. 2, 2017. Retrieved from: http://mir-nauki.com/PDF/23PDMN217.pdf

[15] A.S. Fomina, "Online training in higher education: methods, content, technologies", Society: sociol., psychol., pedag., no. 1, pp. 101-106, 2016.

[16] E.P. Ilyin, Motivation and motives. SPb.: Peter, 2002, 512 p.

[17] V.I. Morosanova, Questionnaire "Style of Behavior Self-regulation SSB-98". Retrieved from: http: //kbmk.org/uploads/kolledj/vosp_ rabota/20170830_izuch_lich_osob.pdf

[18] A.A. Karasik, Models of using online courses in the training process of educational organizations. Retrieved from: https://openedu.urfu.ru/ files/seminar/Карасик \%20Семинар \%20030718 \%20Модели.pdf

[19] M.B. Lebedeva, "Mass open online courses as a trend in the education development", Man and ed., vol. 1, no. 42, pp. 105-108, 2015.

[20] I.G. Gerashchenko, N.V. Gerashchenko, "Issues of distance education: methodological aspect", Studia Human., vol. 2, 2017. Retrieved from: www.st-hum.ru. 
[21] Rector of the Higher School of Economics suggested introducing online courses instead of lectures of tutors without scientific papers. Retrieved from: https://tass.ru/obschestvo/4988218
[22] Opinion. The Trouble With Online College, The New York Times. Retrieved from: https://www.nytimes.com/2013/02/19/opinion/thetrouble-with-online-college.html 